\title{
Magnitude and determinants of interactions between dentists and dental supply representatives in Saudi Arabia
}

\author{
Fahad Alosaimi ${ }^{1}$ and Abdulaziz Albaker ${ }^{2}$
}

${ }^{1}$ Department of Psychiatry, King Saud University, Riyadh, Saudi Arabia. ${ }^{2}$ Department of Prosthetic Dental Sciences, College of Dentistry, King Saud University, Riyadh, Saudi Arabia (Correspondence to: Abdulaziz Albaker: aalbaker@ksu.edu.sa).

\begin{abstract}
Background: The relationship between dentists and dental supply representatives is not as well known as that between physicians and pharmaceutical sales representatives.

Aims: To estimate the magnitude, associated factors and characteristics of the interaction between dentists and dental supply representatives in Saudi Arabia.

Methods: A cross-sectional survey was conducted among dentists working in major governmental and private hospitals in different regions of Saudi Arabia. A self-administered questionnaire was distributed to all participants, either in electronic or paper format, depending on the proximity of the participants. A total of 672 participants completed the survey (response rate, $67.2 \%$ ).

Results: Approximately 68\% of participants reported an interaction with dental supply representatives. Saudi dentists had a lower interaction with dental supply representatives than non-Saudi dentists (65.1\% vs $73.1 \%)$. Dentists working in private hospitals had more interactions with dental supply representatives than those working in public hospitals (78.1\% vs $63.2 \%)$. Compared to residents and interns, dental consultants and specialists had more interactions with dental supply representatives. Dentists who had a prior history of working abroad showed more interactions with dental supply representatives than those with no such history (75.9\% vs $63.7 \%$ ). Multivariate logistic regression analysis showed that the following characteristics were independently associated with greater dentist-dental supply representatives interaction: male sex, older age, living in the eastern region, unsure about income satisfaction, certain job titles (such as specialists), and certain specialties.

Conclusion: Dentists have a high number of interactions with dental supply representatives in Saudi Arabia. Most of the issues identified are common to those seen in other parts of the world.

Keywords: dentists, dental supply representatives, gifts, dental practice, Saudi Arabia

Citation: Alosaimi F; Albaker A. Magnitude and determinants of interactions between dentists and dental supply representatives in Saudi Arabia. East Mediterr Health J. 2020;26(3):356-364. https://doi.org/10.26719/emhj.19.067

Received: 13/09/17, Accepted: 13/03/18

Copyright (C) World Health Organization (WHO) 2020. Open Access. Some rights reserved. This work is available under the CC BY-NC-SA 3.0 IGO license (https://creativecommons.org/licenses/by-nc-sa/3.o/igo).
\end{abstract}

\section{Introduction}

There is an environment of mutual trust between dentists and their patients that forces dentists to provide a good service while adhering to high ethical norms (1). Drawing parallels between the dental product and pharmaceutical industries, the World Health Organization has disclosed that the global pharmaceuticals market is worth US\$300 billion a year with a soaring profit margin of about $30 \%$ (2). These companies currently spend one third of their sales revenue on marketing their products; roughly twice what they spend on research and development (2).

Previous studies reported a significant relationship between physicians and the pharmaceutical industry (3-5). There is ample evidence that these relationships significantly affect physicians' decision-making in their clinical practice and research (6-8). There is a high level of interaction between physicians and pharmaceutical sales representatives in many countries in spite of having restrictive guidelines (9-11) and evidence of adverse effects on physicians' behaviour (3-5). Similarly, a recent study reported a high level of interaction of physicians with pharmaceutical sales representatives in Saudi Arabia (12). Other studies indicated that many physicians in Saudi Arabia often accept gifts from pharmaceutical companies (13), and promotion of pharmaceutical products by physicians is common in Japan (14).

It is clear from the literature that the issue of dental specialists having an unethical relationship with dental supply representatives is not as well known as that of medical specialists with pharmaceutical sales representatives $(15,16)$. With an extensive variety of present day dental products, dental supply companies have begun to develop new procedures to entice dental practitioners to purchase their items and thereby increase their net revenue. Eventually, this has opened the door for advertising practices similar to those in the pharmaceutical industry $(17,18)$.

Some studies have assessed the relationship between physicians and pharmaceutical sales representatives in Saudi Arabia $(12,13)$; however, no such studies have been conducted among dentists in Saudi Arabia. Other studies 
have reported the negative effects of these relationships on patient treatment and care $(5,19)$. Therefore, the present study aimed to determine the magnitude, risk factors and characteristics of dentist-dental supply representative interactions in Saudi Arabia.

\section{Methods}

The present study was conducted among dentists working in major governmental (public) and private hospitals in Central, Eastern, Western, Northern and Southern Saudi Arabia. A total of 63 public and 50 private hospitals were identified and 25 public and 20 private hospitals were included in the study by simple random sampling. All ranks of dentists, including general and specialists, participated. The dental supply representatives were defined as sales representatives of companies that supply dental equipment and materials to dentists, and who visit dentists to provide information about their products.

A self-administrated questionnaire that comprised 50 items arranged in two sections in the English language was developed and distributed to all participants. The first section included questions related to sociodemographic factors, such as age, sex, nationality, monthly income, income satisfaction, hospital setting, and occupational characteristics, such as job rank, specialty, and working duration. The second section included questions related to the interaction with dental supply representatives, gift acceptance and opinion of dentists regarding gift acceptance in dental practice. The scientific content of the questionnaire was validated by a multidisciplinary committee, including specialists in psychiatry, ethics, dentistry and epidemiology. The questionnaire was piloted on a small number of participants. The required changes in the questionnaire were made based on feedback from the pilot data. The original version of this questionnaire targeting physicians' attitudes towards interaction with the pharmaceutical industry was developed and validated by the first author and reported previously (12). The questionnaires were distributed through email with 2 or 3 reminders at an interval of 1 week to dentists in all 5 regions of Saudi Arabia.

Informed consent was obtained from all the participants after explaining the objectives of the study. The study was approved by the Ethical Committee of the College of Dentistry at King Saud University, Riyadh, Saudi Arabia.

The sample size was calculated using OpenEpi version 2.2 (Copyright 2003, 2007 Andrew G. Dean and Kevin M. Sullivan, Atlanta, GA, USA). It was indicated that $\geq 600$ participants were needed to detect a $20 \%$ difference in the given characteristics between the two study groups (400 dentists from public hospitals and 200 from private hospitals), with $95 \%$ confidence level and 0.8 power. The total number of participants was adjusted to allow $10 \%$ of possible missing data.

Data were presented as the mean and standard deviation (SD) for continuous data and frequencies and percentages for categorical data. The prevalence of interaction was reported as the percentage of dentists that interacted with the dental supply representatives. Sociodemographic, occupational and economic factors were compared between dentists who had an interaction with dental supply representatives and those who did not. Significant differences between the 2 groupswereassessed using the $\chi^{2}$ test for categorical data and Student's t test for continuous data. Characteristics that were significantly associated with dentist-dental supply representative interaction in univariate analysis were entered into a multiple logistic regression model to define independent relationships. Variables with $P<0.05$ were retained in the model using conditional backward stepwise elimination. All data were considered statistically significant at $P<0.05$. SPSS version 16.0 (SPSS Inc., Chicago, IL, USA) was used for all statistical analyses.

\section{Results}

A total of 1000 questionnaires was distributed. A total of 672 participants completed the questionnaire (response rate, $67.2 \%$ ). Table 1 details the sociodemographic characteristics of the participants. Approximately 56\% participants were male and the average age was 35.7 (9.4) years. Table 2 details the occupational characteristics of the study participants. Almost $70 \%$ of the participants were working in public (i.e. governmental) hospitals. The average working experience of the participant was 10.6 (9.4) years.

Approximately 68\% ( $n=454)$ participants reported an interaction with dental supply representatives. As shown in Tables 1 and 2, the frequency of interaction with dental supply representatives was significantly higher for male dentists, older age, non-Saudi nationals, living in eastern region, unsure income satisfaction, studying abroad, having ethical education, lack of knowledge about rules and policies regulating the dentist-industry relationships, working in private hospitals, certain job titles, working duration 10-19 years, working abroad, orthodontic specialty and less-common specialties (such as implantologist), and treating patients of high socioeconomic class. In multivariate logistic regression analysis, the following characteristics were independently associated with more dentist-dental supply representative interaction; male sex, older age, living in eastern region, unsure income satisfaction, certain job titles (such as specialists), and certain specialties (Table 3).

Table 4 details the characteristics of the dentistdental supply representative interactions. The majority of interactions ( $\mathrm{n}=327,74.8 \%$ ) occurred at a rate of once or less in a month. The dental clinic was the commonest (n $=169,39.0 \%$ ) place of interaction, followed by conference or symposium ( $n=168,38.8 \%$ ), office ( $n=66,15.2 \%$ ) or other places $(n=30,6.9 \%)$. Approximately $84 \%(n=354)$ of dental supply representatives offered gifts and the majority of dentists ( $n=197,56 \%$ ) often or almost always accepted these gifts. The most common gifts offered 


\begin{tabular}{|c|c|c|c|c|}
\hline \multirow[t]{2}{*}{ Characteristics } & \multirow{2}{*}{$\begin{array}{c}\text { Overall } \\
(n=672)\end{array}$} & \multicolumn{2}{|c|}{ Interactions with DSR } & \multirow[t]{2}{*}{$\mathbf{P}$} \\
\hline & & No $(n=218)$ & Yes $(n=454)$ & \\
\hline \multicolumn{5}{|l|}{ Sex } \\
\hline Male & $376(56.0 \%)$ & $104(27.7 \%)$ & $272(72.3 \%)$ & \multirow[t]{2}{*}{0.003} \\
\hline Female & $296(44.0 \%)$ & $114(38.5 \%)$ & $182(61.5 \%)$ & \\
\hline \multicolumn{5}{|l|}{ Age $(y r)$} \\
\hline Mean (SD) & $35.7(9.4)$ & $33.5(9.9)$ & $36.7(9.0)$ & \multirow{5}{*}{$\begin{array}{l}<0.001 * \\
<0.001\end{array}$} \\
\hline $20-29$ & $241(35.9 \%)$ & $111(46.1 \%)$ & $130(53.9 \%)$ & \\
\hline $30-39$ & $213(31.7 \%)$ & $51(23.9 \%)$ & $162(76.1 \%)$ & \\
\hline $40-49$ & $159(23.7 \%)$ & $41(25.8 \%)$ & $118(74.2 \%)$ & \\
\hline$\geq 50$ & $59(8.8 \%)$ & $15(25.4 \%)$ & $44(74.6 \%)$ & \\
\hline \multicolumn{5}{|l|}{ Nationality } \\
\hline Saudi & $464(69.0 \%)$ & $162(34.9 \%)$ & $302(65.1 \%)$ & \multirow[t]{2}{*}{0.041} \\
\hline Non-Saudi & $208(31.0 \%)$ & $56(26.9 \%)$ & $152(73.1 \%)$ & \\
\hline \multicolumn{5}{|l|}{ Saudi region } \\
\hline Central & $374(55.7 \%)$ & $135(36.1 \%)$ & $239(63.9 \%)$ & \multirow[t]{5}{*}{0.005} \\
\hline Eastern & $83(12.4 \%)$ & $15(18.1 \%)$ & $68(81.9 \%)$ & \\
\hline Western & $122(18.2 \%)$ & $32(26.2 \%)$ & $90(73.8 \%)$ & \\
\hline Northern & $16(2.4 \%)$ & $8(50.0 \%)$ & $8(50.0 \%)$ & \\
\hline Southern & $77(11.5 \%)$ & $28(36.4 \%)$ & $49(63.6 \%)$ & \\
\hline \multicolumn{5}{|l|}{ Monthly income (SAR) } \\
\hline$<10000$ & $117(17.4 \%)$ & $45(38.5 \%)$ & $72(61.5 \%)$ & \multirow[t]{5}{*}{0.273} \\
\hline $10000-19000$ & $240(35.7 \%)$ & $83(34.6 \%)$ & $157(65.4 \%)$ & \\
\hline $20000-29000$ & $119(17.7 \%)$ & $31(26.1 \%)$ & $88(73.9 \%)$ & \\
\hline $30000-39000$ & $103(15.3 \%)$ & $31(30.1 \%)$ & $72(69.9 \%)$ & \\
\hline$\geq 40000$ & $93(13.8 \%)$ & $28(30.1 \%)$ & $65(69.9 \%)$ & \\
\hline \multicolumn{5}{|l|}{ Additional income } \\
\hline Yes & $118(17.6 \%)$ & $35(29.7 \%)$ & $83(70.3 \%)$ & \multirow[t]{2}{*}{0.478} \\
\hline No & $554(82.4 \%)$ & $183(33.0 \%)$ & $371(67.0 \%)$ & \\
\hline \multicolumn{5}{|l|}{ Other income sources } \\
\hline Private clinic & $605(90.0 \%)$ & $190(31.4 \%)$ & $415(68.6 \%)$ & \multirow[t]{3}{*}{0.186} \\
\hline Academic or military duties & $12(1.8 \%)$ & $4(33.3 \%)$ & $8(66.7 \%)$ & \\
\hline Other nonmedical sources & $55(8.2 \%)$ & $24(43.6 \%)$ & $31(56.4 \%)$ & \\
\hline \multicolumn{5}{|l|}{ Income satisfaction } \\
\hline Satisfied & $375(55.8 \%)$ & $110(29.3 \%)$ & $265(70.7 \%)$ & \multirow[t]{3}{*}{0.008} \\
\hline Not sure & $91(13.5 \%)$ & $24(26.4 \%)$ & $67(73.6 \%)$ & \\
\hline Dissatisfied & $206(30.7 \%)$ & $84(40.8 \%)$ & $122(59.2 \%)$ & \\
\hline \multicolumn{5}{|l|}{ Study abroad } \\
\hline Yes & $304(45.2 \%)$ & $83(27.3 \%)$ & $221(72.7 \%)$ & \multirow[t]{2}{*}{0.010} \\
\hline No & $368(54.8 \%)$ & $135(36.7 \%)$ & $233(63.3 \%)$ & \\
\hline Ethical education & & & & \\
\hline Yes & $299(44.5 \%)$ & $68(22.7 \%)$ & $231(77.3 \%)$ & $<0.001$ \\
\hline No & $373(55 \cdot 5 \%)$ & $150(40.2 \%)$ & $223(59.8 \%)$ & \\
\hline Types of ethical education & & & & \\
\hline Lectures & $190(63.5 \%)$ & $49(25.8 \%)$ & $141(74.2 \%)$ & 0.132 \\
\hline Workshops & $72(24.1 \%)$ & $15(21.4 \%)$ & $55(78.6 \%)$ & \\
\hline Courses & $37(12.4 \%)$ & $4(10.8 \%)$ & $33(89.2 \%)$ & \\
\hline Knowledge of rules and policies & & & & \\
\hline Yes & $162(24.1 \%)$ & $63(38.9 \%)$ & $99(61.1 \%)$ & 0.044 \\
\hline No & $510(75.9 \%)$ & $155(30.4 \%)$ & $355(69.6 \%)$ & \\
\hline
\end{tabular}




\begin{tabular}{|c|c|c|c|c|}
\hline \multirow[t]{2}{*}{ Characteristics } & \multirow{2}{*}{$\begin{array}{l}\text { Overall } \\
(n=672)\end{array}$} & \multicolumn{2}{|c|}{ Interactions with DSR } & \multirow[t]{2}{*}{$\mathbf{P}$} \\
\hline & & No $(n=218)$ & Yes $(n=454)$ & \\
\hline \multicolumn{5}{|l|}{ Type of hospital } \\
\hline Public (governmental) & $462(68.8 \%)$ & $170(36.8 \%)$ & $292(63.2 \%)$ & \multirow[t]{3}{*}{0.002} \\
\hline Private (nongovernmental) & $128(19.0 \%)$ & $28(21.9 \%)$ & $100(78.1 \%)$ & \\
\hline Both (working partly in public and private) & $82(12.2 \%)$ & $20(24.4 \%)$ & $62(75.6 \%)$ & \\
\hline \multicolumn{5}{|l|}{ Main dentist assignment } \\
\hline Clinical & $472(70.2 \%)$ & $155(32.8 \%)$ & $317(67.2 \%)$ & \multirow[t]{2}{*}{0.735} \\
\hline Academic & $200(29.8 \%)$ & $63(31.5 \%)$ & $137(68.5 \%)$ & \\
\hline \multicolumn{5}{|l|}{ Clinical job rank } \\
\hline Consultant & $59(8.8 \%)$ & $13(22.0 \%)$ & $46(78.0 \%)$ & \multirow[t]{10}{*}{$<0.001$} \\
\hline Specialist & $132(19.6 \%)$ & $28(21.2 \%)$ & $104(78.8 \%)$ & \\
\hline Resident & $209(31.1 \%)$ & $73(34.9 \%)$ & $136(65.1 \%)$ & \\
\hline Intern & $44(6.5 \%)$ & $25(56.8 \%)$ & $19(43.2 \%)$ & \\
\hline Professor & $31(4.6 \%)$ & $15(48.4 \%)$ & $16(51.6 \%)$ & \\
\hline Associate Professor & $70(10.4 \%)$ & $20(28.6 \%)$ & $50(71.4 \%)$ & \\
\hline Assistant Professor & $24(3.6 \%)$ & $4(16.7 \%)$ & $20(83.3 \%)$ & \\
\hline Demonstrator & $64(9.5 \%)$ & $20(31.2 \%)$ & $44(68.8 \%)$ & \\
\hline Lecturer & $11(1.6 \%)$ & $4(36.4 \%)$ & $7(63.6 \%)$ & \\
\hline General practitioner & $28(4.2 \%)$ & $16(57.1 \%)$ & $12(42.9 \%)$ & \\
\hline \multicolumn{5}{|l|}{ Working duration (yr) } \\
\hline Mean (SD) & $10.6(9.4)$ & $8.9(9.3)$ & $11.4(9.3)$ & $0.001^{*}$ \\
\hline $0-9$ & $365(54.3 \%)$ & $146(40.0 \%)$ & $219(60.0 \%)$ & \multirow[t]{3}{*}{$<0.001$} \\
\hline $10-19$ & $192(28.6 \%)$ & $25(13.0 \%)$ & $167(87.0 \%)$ & \\
\hline$\geq 20$ & $115(17.1 \%)$ & $47(40.9 \%)$ & $68(59.1 \%)$ & \\
\hline \multicolumn{5}{|l|}{ Work abroad } \\
\hline Yes & $212(31.5 \%)$ & $51(24.1 \%)$ & $161(75.9 \%)$ & \multirow[t]{2}{*}{0.002} \\
\hline No & $460(68.5 \%)$ & $167(36.3 \%)$ & $293(63.7 \%)$ & \\
\hline \multicolumn{5}{|l|}{ Specialty } \\
\hline Oral and maxillofacial surgery & $20(3.0 \%)$ & $4(20.0 \%)$ & $16(80.0 \%)$ & \multirow[t]{10}{*}{$<0.001$} \\
\hline Oral medicine and diagnostics & $45(6.7 \%)$ & $12(26.7 \%)$ & $33(73.3 \%)$ & \\
\hline Periodontics & $50(7.4 \%)$ & $21(42.0 \%)$ & $29(58.0 \%)$ & \\
\hline Paediatric dentistry & $41(6.1 \%)$ & $24(58.5 \%)$ & $17(41.5 \%)$ & \\
\hline Orthodontics & $29(4.3 \%)$ & $4(13.8 \%)$ & $25(86.2 \%)$ & \\
\hline Prosthetic dentistry & $108(16.1 \%)$ & $36(33.3 \%)$ & $72(66.7 \%)$ & \\
\hline Restorative dentistry & $71(10.6 \%)$ & $19(26.8 \%)$ & $52(73.2 \%)$ & \\
\hline Endodontics & $80(11.9 \%)$ & $26(32.5 \%)$ & $54(67.5 \%)$ & \\
\hline Others & $16(2.4 \%)$ & $0(0.0 \%)$ & $16(100.0 \%)$ & \\
\hline Not specialized & $212(31.5 \%)$ & $72(34.0 \%)$ & $140(66.0 \%)$ & \\
\hline \multicolumn{5}{|l|}{ Patients' socioeconomic status } \\
\hline Not sure & $76(11.3 \%)$ & $40(52.6 \%)$ & $36(47.4 \%)$ & \multirow[t]{4}{*}{$<0.001$} \\
\hline Lower & $160(23.8 \%)$ & $79(49.4 \%)$ & $81(50.6 \%)$ & \\
\hline Middle & $389(57.9 \%)$ & $91(23.4 \%)$ & $298(76.6 \%)$ & \\
\hline Upper & $47(7.0 \%)$ & $8(17.0 \%)$ & $39(83.0 \%)$ & \\
\hline
\end{tabular}

\section{${ }^{*}$ t test, otherwise $\chi^{2}$ test.}

$D S R=$ dental supply representative; $S A R=$ Saudi riyal $; D=$ standard deviation.

were free instruments samples ( $n=162,55.6 \%$ ), followed by sponsorship for attending educational training $(\mathrm{n}=$ $57,19.3 \%$ ) and stationery items such as pens and notepads $(\mathrm{n}=32,10.8 \%)$.

\section{Discussion}

To the best of our knowledge, the current study is the first to investigate the magnitude, associated factors and characteristics of the interaction between dentists and dental 


\begin{tabular}{|c|c|c|c|c|c|}
\hline \multirow[t]{2}{*}{ Characteristics } & \multirow[t]{2}{*}{ Reference group } & \multirow[t]{2}{*}{ OR } & \multicolumn{2}{|c|}{ CI } & \multirow[t]{2}{*}{$\boldsymbol{P}$} \\
\hline & & & Lower & Upper & \\
\hline Male & Female & 1.82 & 1.16 & 2.84 & 0.009 \\
\hline Age (yr) & & 1.05 & 1.01 & 1.08 & 0.006 \\
\hline \multicolumn{6}{|l|}{ Saudi region } \\
\hline & Central & & & & 0.006 \\
\hline Eastern & & 2.33 & 1.17 & 4.61 & 0.016 \\
\hline Western & & 1.10 & 0.59 & 2.04 & 0.763 \\
\hline Northern & & 0.33 & 0.10 & 1.10 & 0.071 \\
\hline Southern & & 0.55 & 0.29 & 1.07 & 0.077 \\
\hline \multicolumn{6}{|l|}{ Income satisfaction } \\
\hline & Dissatisfied & & & & 0.03 \\
\hline Satisfied & & 1.50 & 0.96 & 2.36 & 0.078 \\
\hline Not-sure & & 2.32 & 1.20 & 4.51 & 0.013 \\
\hline \multicolumn{6}{|l|}{ Job rank } \\
\hline & Intern / GP / demonstrator & & & & 0.002 \\
\hline Consultant / prof / associate prof & & 0.80 & 0.30 & 2.12 & 0.651 \\
\hline Specialist / assistant prof & & 2.81 & 1.27 & 6.21 & 0.011 \\
\hline Resident / lecturer & & 0.88 & 0.49 & 1.58 & 0.677 \\
\hline \multicolumn{6}{|l|}{ Specialty } \\
\hline & Not specialized & & & & 0.004 \\
\hline Oral and maxillofacial surgery & & 0.85 & 0.23 & 3.09 & 0.806 \\
\hline Oral medicine and diagnostics & & 0.58 & 0.25 & 1.39 & 0.222 \\
\hline Periodontics & & 0.54 & 0.25 & 1.17 & 0.118 \\
\hline Paediatric dentistry & & 0.18 & 0.07 & 0.48 & 0.001 \\
\hline Orthodontics & & 3.83 & 1.08 & 13.64 & 0.038 \\
\hline Prosthetic dentistry & & 0.71 & 0.35 & 1.45 & 0.341 \\
\hline Restorative dentistry & & 0.39 & 0.18 & 0.83 & 0.014 \\
\hline Endodontics & & 0.43 & 0.20 & 0.90 & 0.026 \\
\hline Others & & $>10$ & 0.00 & - & 0.998 \\
\hline \multicolumn{6}{|l|}{ Patients' socioeconomic status } \\
\hline & Not sure & & & & $<0.001$ \\
\hline Lower & & 0.87 & 0.44 & 1.74 & 0.695 \\
\hline Middle & & 3.40 & 1.84 & 6.27 & $<0.001$ \\
\hline Upper & & 3.12 & 1.14 & 8.55 & 0.027 \\
\hline
\end{tabular}

$\mathrm{CI}=$ confidence interval; $\mathrm{DSR}=$ dental supply representative; $\mathrm{GP}=$ general practitioner; $\mathrm{OR}=$ odds ratio.

supply representativesin Saudi Arabia. The results showed that two thirds of the participants had interaction with dental supply representatives on a regular basis that was comparable to that reported among physicians in Saudi Arabia (72.9\%) and other parts of the world (12). In addition, the current study suggested that dentist-dental supply representative interaction varied according to dentists' personal and professional characteristics and their practice setting. For example, orthodontists and specialists were more likely to interact with the dental supply representatives compared to paediatric dentists. Previous studies reported approximately $90 \%$ prevalence of physician-pharmaceutical sales representative interaction in surveys of multi-specialty cohorts $(20,21)$ and single-specialty cohorts such as ophthalmology trainees (22) and psychiatrists (23). Similarly, other studies reported a high prevalence of physician-

\begin{tabular}{|c|c|}
\hline \multicolumn{2}{|c|}{$\begin{array}{l}\text { Table } 4 \text { Characteristics of the interactions between dentists } \\
\text { and dental supply representatives }\end{array}$} \\
\hline \multicolumn{2}{|l|}{ Characteristics } \\
\hline \multicolumn{2}{|l|}{ Frequency of interaction } \\
\hline$\leq 1 /$ month & $327(74.8 \%)$ \\
\hline 2 or 3 times/month & $47(10.8 \%)$ \\
\hline Once weekly & $27(6.2 \%)$ \\
\hline 2-5 times/week & $24(5.5 \%)$ \\
\hline Nearly every day & $12(2.7 \%)$ \\
\hline \multicolumn{2}{|l|}{ Place of interaction } \\
\hline Clinic & $169(39.0 \%)$ \\
\hline During hours & $140(32.3 \%)$ \\
\hline After hours & $29(6.7 \%)$ \\
\hline Office & $66(15.2 \%)$ \\
\hline
\end{tabular}




\section{Table 4 Characteristics of the interactions between dentists} and DSRs (concluded)

\begin{tabular}{|c|c|}
\hline \multicolumn{2}{|l|}{ Characteristics } \\
\hline \multicolumn{2}{|l|}{ Place of interaction } \\
\hline Conference/symposium & $168(38.8 \%)$ \\
\hline Others & $30(6.9 \%)$ \\
\hline \multicolumn{2}{|l|}{ Duration of interactions (min) } \\
\hline$<5$ & $40(9.8 \%)$ \\
\hline $5-9$ & $155(38.0 \%)$ \\
\hline $10-14$ & $148(36.3 \%)$ \\
\hline $15-30$ & $40(9.8 \%)$ \\
\hline$>30$ & $25(6.1 \%)$ \\
\hline \multicolumn{2}{|l|}{ Communication methods } \\
\hline Telephone & $128(45.2 \%)$ \\
\hline Face-to-face & $77(27.2 \%)$ \\
\hline E-mail & $58(20.5 \%)$ \\
\hline More than one method & $20(7.1 \%)$ \\
\hline \multicolumn{2}{|l|}{ Gift offer } \\
\hline No & $67(15.9 \%)$ \\
\hline Yes & $354(84.1 \%)$ \\
\hline \multicolumn{2}{|l|}{ Gift acceptance } \\
\hline Never & $33(9.3 \%)$ \\
\hline Rarely & $53(15.0 \%)$ \\
\hline Sometimes & $71(20.1 \%)$ \\
\hline Often & $102(28.8 \%)$ \\
\hline Almost always & $95(26.8 \%)$ \\
\hline \multicolumn{2}{|l|}{ Reasons for accepting gift offers } \\
\hline Helps me to remember their products & $117(37.9 \%)$ \\
\hline Human nature to accept gifts & $61(19.7 \%)$ \\
\hline Minor gifts are always welcomed & $59(19.1 \%)$ \\
\hline Do not want to say no & $49(15.9 \%)$ \\
\hline Gifts are present in every profession, not only in dentistry & $12(3.9 \%)$ \\
\hline My colleagues are accepting gifts & $7(2.3 \%)$ \\
\hline Salaries of dentists are inadequate & $4(1.3 \%)$ \\
\hline \multicolumn{2}{|l|}{ Type of gift } \\
\hline Free instruments samples & $162(54.7 \%)$ \\
\hline Attend industry-sponsored CME events & $45(15.2 \%)$ \\
\hline Attend non-industry-sponsored CME events & $12(4.1 \%)$ \\
\hline Stationary such as pens or note pads & $32(10.8 \%)$ \\
\hline Funded research & $21(7.1 \%)$ \\
\hline Free meals & $20(6.8 \%)$ \\
\hline Prepaid promotion cards/codes & $4(1.4 \%)$ \\
\hline \multicolumn{2}{|l|}{ Gifts with company's name or logo } \\
\hline Yes & $256(80.8 \%)$ \\
\hline No & $32(10.1 \%)$ \\
\hline Don't know & $29(9.1 \%)$ \\
\hline \multicolumn{2}{|l|}{ Reasons for prescribing a dental material } \\
\hline To benefit patients with economic incapability & $87(31.3 \%)$ \\
\hline Due to availability of these samples & $101(36.3 \%)$ \\
\hline According to the patients convenience & $32(11.5 \%)$ \\
\hline The sample is more effective & $58(20.9 \%)$ \\
\hline
\end{tabular}

PSR interaction in Libya (24) and Japan (14). However, in the current study, most of the dentist-dental supply representative interactions occurred at a rate of once or less per month, which is lower than reported for physicianPSR interaction. One review states that $80-90 \%$ of physicians in the United States of America, United Kingdom of Great Britain and Northern Ireland, Canada, and New Zealand meet pharmaceutical sales representatives twice a month on average (7). Another study reported higher rates of physician-pharmaceutical sales representative interactions ranging from 5 to 10 times per month based on specialty (14).

Most of the dentist-dental supply representative interactions take place at the dental clinic or in the office during clinical hours or later, which is indicative of a tolerant work environment. The fact that most patients belong to middle or lower economic strata means that social responsibility should go hand-in-hand with professional obligation $(25,26)$. Therefore, mutual trust between dentists and patients is important and it should be nurtured at all levels of treatment. When patient rights and interests are protected, dentists also become protected because most of the existing laws fulfil the ethical obligations of dentists to safeguard the patients' best interests as primary (27-29).

Acceptance of gifts by dentists in the current study was lower than that reported previously. In the study of Alosaimi et al. (13), approximately $80 \%$ of the physicians had accepted some type of pharmaceutical gift. Similarly, other studies reported a high rate of acceptance of pharmaceutical gifts from the pharmaceutical sales representatives $(14,21,30,31)$. The commonest reason for accepting gifts stated by dentists was that these gifts helped them to remember their products. One of the previous studies reported that physicians considered that small gifts were not ethically wrong (14). In the current study, the most common gifts offered were free instruments samples, followed by sponsorship for attending educational training, and stationery items such as pens and notepads. In a previous study, smaller gifts such as trinkets, meals and books were more commonly given to physicians; however, costly gifts such as air travel and hotel accommodation were given selectively (32).

Multivariate logistic regression analysis showed various characteristics of the dentists that influenced their interactions with dental supply representatives. Male dentists had more interaction with dental supply representatives than female dentists had. In contrast, a previous study reported a nonsignificant effect of sex on physician-pharmaceutical sales representative interaction (12). However, a direct comparison could not be made as the previous study was of physicians rather than dentists. The sex difference could be explained by the fact that more male dentists worked in private hospitals, where they were more likely to interact with dental supply representatives. In the current study, dentists working in Eastern Saudi Arabia had greater interaction 
with dental supply representatives than dentists in other regions had. Similarly, a previous study reported greater interactions between physicians and pharmaceutical sales representatives working in the eastern region (12). In the current study, clinical job rank of the dentists was associated with the interactions between dentists and dental supply representatives. For instance, specialists and assistant professors had greater interaction with dental supply representatives compared to others. Similarly, a previous study reported a greater interaction between medical specialists and dental supply representatives (12). In the present study, some of the specialties, such as paediatric dentistry, orthodontics, restorative dentistry, and endodontics, had more interaction with dental supply representatives than others had. Similarly, a previous study reported greater interaction between some medical specialties and pharmaceutical sales representatives in Saudi Arabia (12).

Owing to lack of ethical education in the dental curriculum, there is a possibility that dental professionals may not be aware of the existing rules and policies in Saudi Arabia that regulate dentist-industry relationships, as in many other countries $(11,20,33)$. Therefore, further research that focuses on ethical, clinical, prescription and economic impacts of dentistry is recommended.

The present study had some limitations. Being a convenience sample, the outcomes ought to be interpreted with caution and not viewed as representative of dental specialists working in Saudi Arabia. Furthermore, it was a self-reported study; therefore, the likelihood of underestimation, because of social desirability bias, could not be avoided, particularly as the association may have included conflicts of interest. Further studies are warranted to assess the impact of dentist-dental supply representative interaction on patients' treatment and care and the overall quality of dental practice in Saudi Arabia.

\section{Conclusion}

The rate of interaction of dentists with dental supply representatives in Saudi Arabia was high, as in other countries where similar studies have been conducted. Orthodontists interacted more often with DSRs than other dentists did. Most dentists interacted with DSRs at a rate of once or less per month. A large number of dentists occasionally accepted small gifts such as free instrument samples and stationary items. Further investigations are required to explore the ethical, clinical and economic impact of dentist-DSR interaction.

Funding: None.

Competng interest: None declared.

\section{Ampleur et déterminants des interactions entre dentistes et représentants dentaires en Arabie saoudite}

\section{Résumé}

Contexte : Les liens entre les dentistes et les représentants dentaires sont moins bien connus que ceux que l'on observe entre les médecins et les représentants commerciaux des sociétés pharmaceutiques.

Objectifs : Évaluer l'ampleur, les facteurs associés et les caractéristiques des interactions entre les dentistes et les représentants dentaires en Arabie saoudite.

Méthodes : Une étude transversale a été menée auprès des dentistes travaillant dans les grands hôpitaux publics et privés de différentes régions d'Arabie saoudite. Un auto-questionnaire a été distribué à l'ensemble des participants, sous format électronique ou papier, en fonction de la proximité de ces derniers. Au total, 672 participants ont répondu à ce questionnaire (taux de réponse de 67,2\%).

Résultats : Près de $68 \%$ des participants ont déclaré avoir des interactions avec les représentants dentaires. Les dentistes saoudiens faisaient état d'un niveau d'interactions moindre avec ces représentants que leurs confrères non saoudiens $(65,1 \%$ contre $73,1 \%$ ). Les dentistes travaillant dans des hôpitaux privés avaient plus d'interactions avec les représentants dentaires que leurs confrères en poste dans les hôpitaux publics (78,1 \% contre 63,2 \%). Les dentistes consultants et les spécialistes faisaient état de davantage d'interactions avec les représentants dentaires que les dentistes résidents et internes. Les dentistes qui, au cours de leur carrière, avaient travaillé à l'étranger avaient plus d'interactions avec les représentants dentaires que leurs confrères n'ayant pas eu ce parcours professionnel (75,9\% contre 63,7\%). L'analyse de régression logistique multivariée a montré que les caractéristiques suivantes étaient associées de manière indépendante à de plus grandes interactions entre les dentistes et les représentants dentaires : sexe masculin, âge plus avancé, résidant dans la Région orientale, incertitude quant à la satisfaction du revenu, certains postes (de spécialistes par exemple) et certaines spécialités.

Conclusions : En Arabie saoudite, les dentistes entretiennent un nombre élevé d'interactions avec les représentants dentaires. La plupart des problèmes identifiés sont communs à ceux observés dans d'autres régions du monde. 
حجم التعاملات بين أطباء الأسنان ومثثلي شركات مستلزمات طب الأسنان في المملكة العربية السعودية ومحددات هذه التعاملات فهد العصيمي، عبد العزيز البكر الخلاصة الخلفية: العلاقة بين أطباء الأسنان ومثثلي شركات مستلزمات طب الأسنان ليست معروفة تماماً مثل العلاقة بين الأطباء البشريين ومثثلي مبيعات المستحضر ات الدوائية.

الأهداف: هدفت الدراسة إلى تقدير حجم التعامل بين أطباء الأسنان ومثثلي شركات مستلزمات اتمات طب الأسنان في المملكة العربية السعودية، وتحديد

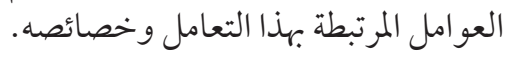

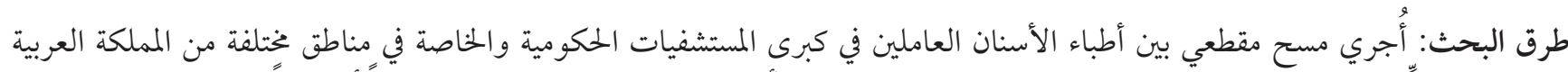

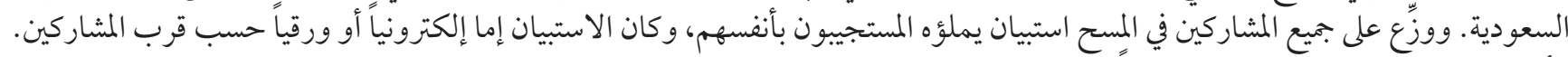

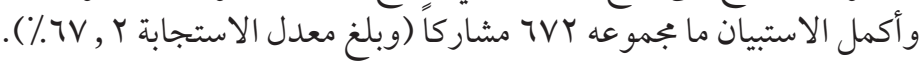

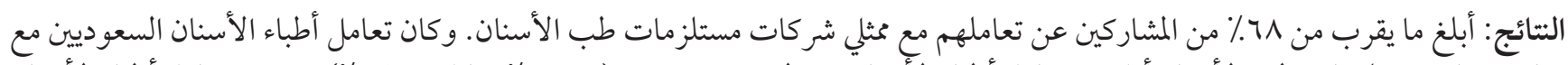

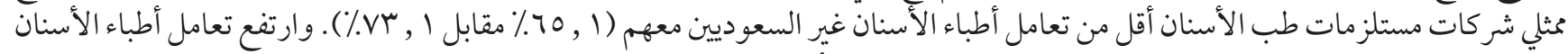

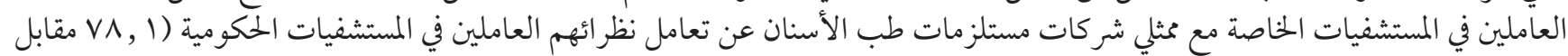

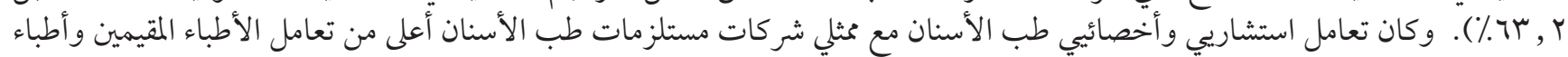

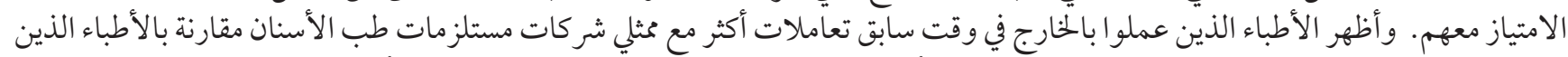

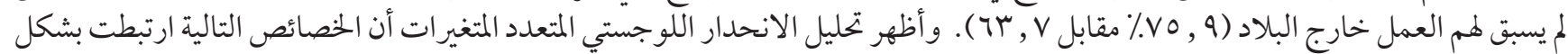

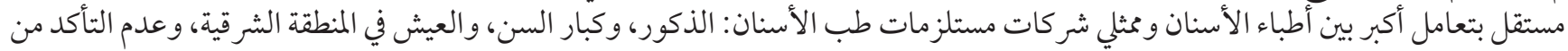

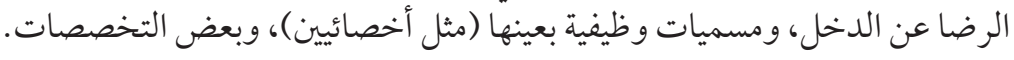

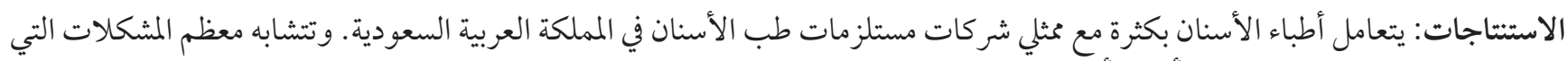

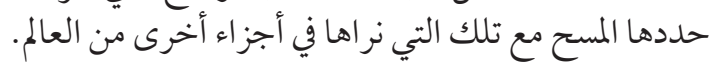

\section{References}

1. Richard JS. Commerce versus care: troubling trends in the ethics of esthetic dentistry. Dent Clin North Am. 2007 Apr; 51(2):281-7. http://dx.doi.org/10.1016/j.cden.2007.03.002 PMID:17532912

2. World Health Organization. Pharmaceutical industry (www.who.int/trade/glossary/storyo73/en/print.html, accessed 18 March, 2009).

3. Peppin JF. Pharmaceutical sales representatives and physicians: ethical considerations of a relationship. J Med Philos 1996 Feb;21(1):83-99. https://doi.org/10.1093/jmp/21.1.83

4. Collins J. Professionalism and physician interactions with industry. J Am Coll Radiol. 2006 May;3(5):325-32. http://dx.doi. org/10.1016/j.jacr.2006.01.022 PMID:17412075

5. Komesaroff PA, Kerridge IH. Ethical issues concerning the relationships between medical practitioners and the pharmaceutical industry. Med J Aust. 2002 Feb 4;176(3):118-21. PMID:11936308

6. Wazana A. Physicians and the pharmaceutical industry: is a gift ever just a gift? JAMA. 2000 Jan 19;283(3):373-80. PMID:10647801

7. Lexchin J. Interactions between physicians and the pharmaceutical industry: what does the literature say? CMAJ. 1993 Nov 15;149(10):1401-7. PMID:8221424

8. Zipkin DA, Steinman MA. Interactions between pharmaceutical representatives and doctors in training. A thematic review. J Gen Intern Med. 2005 Aug;20(8):777-86. http://dx.doi.org/10.1111/j.1525-1497.2005.0134.x PMID:16050893

9. American College of Clinical Pharmacy. Pharmacists and the pharmaceutical industry: guidelines for ethical interactions. Pharmacotherapy. 1993 Sep-Oct;13(5):531-3. https://doi.org/10.1002/j.1875-9114.1993.tbo4323.x

10. Guidelines for interactions with pharmaceutical companies. JAMA. 1993 Sep 8;270(10):1250. http://dx.doi.org/10.1001/ jama.1993.03510100100042

11. Komesaroff PA. Ethical issues in the relationships with industry: an ongoing challenge. New Guidelines open for public comment. J Paediatr Child Health. 2005 Nov 3;41(11):558-60. https://doi.org/10.1111/j.1440-1754.2005.00719.x

12. Alosaimi FD, Alkaabba A, Qadi M, Albahlal A, Alabdulkarim Y, Alabduljabbar M, et al. Interactions between physicians and pharmaceutical sales representatives in Saudi Arabia. Ann Saudi Med. 2013 Nov-Dec;33(6):601-9. PMCID: http://dx.doi. org/10.5144/0256-4947.2013.601 PMID: 24413866 
13. Alosaimi F, Alkaabba A, Qadi M, Albahlal A, Alabdulkarim Y, Alabduljabbar M, et al. Acceptance of pharmaceutical gifts. Variability by specialty and job rank in a Saudi healthcare setting. Saudi Med J. 2013 Aug;34(8):854-60. PMID:23974459

14. Saito S, Mukohara K, Bito S. Japanese practicing physicians' relationships with pharmaceutical representatives: a national survey. PLoS One. 2010 Aug 13;5(8):e12193. http://dx.doi.org/10.1371/journal.pone.0012193 PMID:20730093

15. Alkhateeb FM, Khanfar NM, Clauson KA. Characteristics of physicians who frequently see pharmaceutical sales representatives. J Hosp Mark Public Relations. 2009;19(1):2-14. https://doi.org/10.1080/15390940802581374

16. Nermin Y. The responsibilities and rights of dental professionals 3. Professional rights. Int Dent J. 2006 Aug;56(4):224-6. PMID:16972397

17. Chiodo GT, Tolle SW, Donohoe MT. Ethical issues in the acceptance of gifts: Part-2. Gen Dent. 1999 Jul-Aug;47(4):357-60. PMID:10687461

18. Nash DA. Professional ethics and esthetic dentistry. J Am Dent Assoc. 1988 Sep; 117(4):7E-9E. PMID:3183255

19. Brennan TA, Rothman DJ, Blank L, Blumenthal D, Chimonas SC, Cohen JJ, et al. Health Industry Practices That Create Conflicts of Interest. a policy proposal for academic medical centers. JAMA. 2006 Jan 25;295(4):429-33. http://dx.doi.org/10.1001/ jama.295.4.429 PMID:16434633

20. Campbell EG, Rao SR, DesRoches CM, Iezzoni LI, Vogeli C, Bolcic-Jankovic D, et al. Physician professionalism and changes in physician-industry relationships from 2004 to 2009. Arch Intern Med. 2010 Nov 8;170(20):1820-6. http://dx.doi.org/10.1001/ archinternmed.2010.383 PMID:21059976

21. Campbell EG, Gruen RL, Mountford J, Miller LG, Cleary PD, Blumenthal D. A national survey of physician-industry relationships. N Engl J Med. 2007 Apr 26;356(17):1742-50. http://dx.doi.org/10.1056/NEJMsa064508 PMID:17460228

22. Wang Y, Adelman RA. A study of interactions between pharmaceutical representatives and ophthalmology trainees. Am J Ophthalmol. 2009 Oct;148(4):619-22. http://dx.doi.org/10.1016/j.ajo.2009.05.011 PMID:19570520

23. Sernyak M, Rosenheck R. Experience of VA psychiatrists with pharmaceutical detailing of antipsychotic medications. Psychiatr Serv. 2007 Oct;58(10):1292-6. http://dx.doi.org/10.1176/ps.2007.58.10.1292 PMID:17914005

24. Alssageer MA, Kowalski SR. A survey of pharmaceutical company representative interactions with doctors in Libya. Libyan J Med 2012;7. http://dx.doi.org/10.3402/ljm.v7io.18556 PMID:23002397

25. Dharamsi S, Pratt DD, MacEntee MI. How dentists account for social responsibility: economic imperatives and professional obligations. J Dent Educ. 2007 Dec;71(12):1583-92. PMID:18096884

26. Presswood R. A philosophy of dental practice. Int J Prosthodont. 1992 Jul-Aug; 5(4):384-5. PMID:1520461

27. Reid KI. Respect for patients' autonomy. J Am Dent Assoc. 2009 Apr;140(4):470-4. PMID:19339539

28. Nermin Y. Dentist-patient relationship and quality care 2. Trust. Int Dent J. 2005 Jun;55(3):168-70. PMID:15997968

29. Hirsch AC, Gert B. Ethics in dental practice. J Am Dent Assoc. 1986 Oct;113(4):599-603. https://doi.org/10.14219/jada.archive.1986.0235

30. Halperin EC, Hutchison P, Barrier RC Jr. A population-based study of the prevalence and influence of gifts to radiation oncologists from pharmaceutical companies and medical equipment manufacturers. Int J Radiat Oncol Biol Phys. 2004 Aug 1;59:147783. http://dx.doi.org/10.1016/j.ijrobp.2004.01.052 PMID:15275735

31. McNeill PM, Kerridge IH, Henry DA, Stokes B, Hill SR, Newby D, et al. Giving and receiving of gifts between pharmaceutical companies and medical specialists in Australia. Intern Med J. 2006 Sep;36(9) 571-8. http://dx.doi.org/10.1111/j.14455994.2006.01151.x PMID:16911549

32. Madhavan S, Amonkar MM, Elliott D, Burke K, Gore P. The gift relationship between pharmaceutical companies and physicians: an exploratory survey of physicians. J Clin Pharm Ther. 1997 Jun;22(3):207-15. PMID:9447476

33. Lantz MS, Bebeau MJ, Zarkowski P. The status of ethics teaching and learning in U.S. dental schools. J Dent Educ. 2011 Oct;75(10):1295-309. PMID:22012772 